\title{
Lifestyle and Medicine in the Enlightenment
}

The Six Non-Naturals in the Long Eighteenth Century

Edited by

James Kennaway and Rina Knoeff

First published 2020

ISBN: 978-1-138-61070-5 (hbk)

ISBN: 978-0-429-46564-2 (ebk)

Chapter 8

"That venerable and princely custom of long-lying abed": Sleep and civility in seventeenthand eighteenth-century urban society

Elizabeth Hunter

(CC BY-NC-ND 4.0)

DOI: $10.4324 / 9780429465642-8$

This OA chapter is funded by Queen Mary University of London.

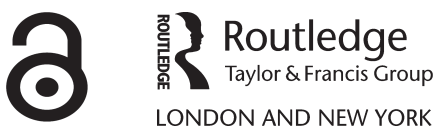




\title{
$8 \quad$ "That venerable and princely custom of long-lying abed"'
}

\author{
Sleep and civility in seventeenth- and \\ eighteenth-century urban society ${ }^{1}$
}

\author{
Elizabeth Hunter
}

\begin{abstract}
"Early to bed and early to rise, and you never meet any prominent people." This ironic twist on a familiar English proverb was attributed to the American writer George Ade in 1928 (Miner and Rawson, 2006, p. 307); but it would have been appreciated in eighteenth-century London where the upper classes and their imitators gained notoriety for excess and late-night revels. A certain degree of night-time socialising was necessary for the purposes of business and social advancement, and it also formed part of an Enlightenment ideal of a cultured and connected society. The excessive pursuit of leisure during the hours of darkness, however, and the period of sleeping during morning hours that inevitably followed, were seen by some as ruinous to the health of the individual and nation. This was not an entirely new concern. As one of the six non-naturals, attention to hours of sleeping and waking was well established in European culture as a way of maintaining health and living to an old age. However, in the midst of anxiety that the old rhythms of day and night were being eroded, popular health manuals, such as those of the famous physician George Cheyne, insisted upon the unnaturalness and unhealthiness of latenight entertainment more strongly than in previous centuries.

This chapter explores how these health concerns became interwoven with debates about proper conduct and masculine identity. Historians of gender and culture have identified the long eighteenth century as a period in which modern concepts of politeness, civility, masculinity and the identity of the "gentleman" were being developed. In particular, a number of historians have detected in this period a shift in the concept of genteel masculinity. Whereas in previous centuries landownership was crucial to a gentleman's identity, the seventeenth and eighteenth centuries saw the emergence of the bourgeois gentleman, who made a living through trade, or the professions, and whose claim to gentlemanly status was based in the respectability of his social interactions and domestic arrangements (Bryson, 1998; Harvey, 2005, pp. 296-311; Tosh, 2014, pp. 219-220). Sleeping habits became a defining factor, distinguishing the "beau" and the "rake" from the "man of business." For some, maintaining a position in urban society, while also remaining healthy and avoiding dissolute company, was a difficult balancing act that was not always achieved. Others deliberately flouted the advice of physicians and conduct books, revelling in the excess associated with wealth and status.
\end{abstract}




\section{"Early to bed and early to rise"}

The spiritual, material and health benefits of early rising are expressed in the English proverb "early to bed and early to rise makes a man healthy, wealthy and wise," commonly associated with the name of Benjamin Franklin. He included it in a 1735 edition of Poor Richard's Almanac, a pamphlet published yearly in the American colonies. He quoted it again in The Way to Wealth, an essay on the benefits of frugality and a strong work ethic (Franklin, 1786, p. 5; Miner and Rawson, 2006, p. 307). The proverb has therefore become associated with the American Dream - the idea that in a free society it is possible for individuals to improve their lives through diligence and innate ability, regardless of birth (Houston, 2008, pp. 3-4). This is in turn based upon Enlightenment values of liberty and the pursuit of happiness.

The saying, however, is not original to Franklin or to the Enlightenment era, but has its origins in the rhythms of rural life in medieval England and the principles of Hippocratic humoral medicine. An early version can be found in a fifteenth-century treatise on angling. The author extols the health-giving benefits of fishing, which, in addition to exposing the sportsman to good air, exercise and the harmonious environment of bird song, is the occasion for him to rise early: for "As the olde englysshe proverb sayth in this wyse. Who soo woll ryse erly shall be holy helthy and zely [fortunate]." Follow this advice, the author urges, for a long old age (treatise of fysshynge, 1496, sig. Hi).

Writing for those with less leisure, an early sixteenth-century book on land management, emphasises the financial wisdom behind the proverb:

Whan thou syttest by ye fyre \& hast souped consydre in thy mynde whether ye warkes yt thou thy wyfe \& thy servantes shall do be more avauntage to the than ye fyre \& candell lyght meat \& drynk yt they shal spende ... \& yf it be nat than go to thy bed \& slepe \& be up betyme \& breake thy fast before day that thou mayst be all the short wynters daye aboute thy busynes.

(Fitzherbert, 1530, fol. Lii)

The modern wording can be found in books of proverbs printed in the seventeenth century, alongside similar sentiments. These included: "One houres sleepe before midnight, is worth three after" (which some collections reduce to a more moderate two); "Go to bed with the lambe, and rise with the lark"; and a now quaint-sounding couplet, which was more specific about exactly what was meant by "early" rising,

He that will thrive must rise by five.

He that hath thriven may lye till seven.

(Clarke, 1639, pp. 91-92, 292; Herbert, 1640, no. 882; Ray, 1678 , p. 38) 
Health manuals from this period did not universally condemn morning sleep; it was thought necessary for the elderly and the sick, and, occasionally, might be permitted after a late night. Generally, however, the hours between sunrise and noon were considered the worst time for sleep in those who were young and healthy. Humoral theory saw the body as a microcosm reacting to changes in light and atmosphere in a way similar to plant life. Sleep during sunlight hours was not simply lazy, but unnatural. "Eschue noon sleeps, and too long morning-sleeps, as great enemies to health," advised the seventeenth-century medical treatise The Skilful Physician, "for whatsoever is not according to the course of Nature, is contrary to Nature, and so will by little and little weaken Nature, and in the end overthrow it" (Bahia, 1656, sig. a5). As the rays of the sun drew the blood and vital spirits to the surface of the body, the day was the natural time for work. Around midnight, when the sun was farthest from the earth, the spirits withdrew into the body, aiding digestion. If this process continued past the natural hour, the body would become dry, and badly concocted humours would rise up to the head causing headaches, rheums and fever. (see Langton, 1547, sig. Hiii; Gratarolo, 1574, pp. 75-76; Vaughan, 1600, p. 75; Paré, 1665, p. 254)

\section{Sleep in the city}

In pre-Enlightenment Europe, the wealthy urban elite had already gained a reputation for bad sleeping habits. The famous Spanish work $A$ Dispraise of the Life of a Courtier (published in English in 1548) painted a picture of worldly court life in the city, where courtiers stayed up late to advance their own affairs and slept past prayer time in the morning (Guevara, 1548, sig. fiii). This was despite the efforts of civic authorities to enforce early modern ideas about the natural rhythms of sleep and rest. In London, the "shutting in of the day" (a phrase sometimes used to refer to the onset of darkness) was a literal event, which took place each night when the seven gates allowing entrance to the City were shut, and "watchmen" patrolled the streets with powers to charge on-the-spot fines for drunken behaviour. They could also arrest anyone who could not give a sufficient reason for being out after dark for the crime of "nightwalking" (Ekirch, 2005, pp. 59-84; Griffiths, 2008, ch. 9). This attempt by the authorities to shut down the City at night was not entirely successful. Historians studying the history of the metropolis have shown that there was a vibrant City night life. People of all ages, and a broad range of social classes, stayed up to drink or gamble in ale houses and taverns. Neighbours complained of noise caused by drunken people in the streets at night (Ekirch, 2005, pp. 185-190; Griffiths, 2008, pp. 332-342).

The sleeping habits and nocturnal pursuits of London's fashionable society became the subject of sharp social criticism. At the turn of the seventeenth century, Thomas Dekker painted a colourful picture of indolent urban life in his satirical work The Gull's Hornbook (1905), first published in 1609. Here he outlines the typical day of a "gull" or would-be "gallant" - a credulous young 
man of dissipated habits who frequented fashionable places. In an early chapter entitled "Rules for the morning [and] in praise of sleep," the gull makes his first appearance in the "softest and largest down-bed" where he stays until noon (Dekker, 1905, p. 23). The chapter plays on the conflict between this decadence and medical wisdom. "Care not for those coarse painted-cloth rhymes," Dekker advises, ironically, "made by the university of Salerne, that come over you with:

Sit brevis aul nullis, tibi somnus meridanus

Short let thy sleep at noon be,

Or rather let it none be.

(Dekker, 1905, p. 23)

The couplet is taken from the well-known medieval didactic poem, Regimen sanitatis Salernitanum (De Mediolano, 1528), and a "painted-cloth rhyme" was a motto painted on canvases used to decorate the walls of medieval and early modern households (Mander, 1997). Dekker's reference suggests that this maxim against midday sleep was a common choice for the bedchamber. However, his Gull is derisive of these learned verses: "Physicians, I know, and none else took up the bucklers in their defence; railing bitterly upon that venerable and princely custom on long-lying-abed." He accuses physicians of a conspiracy to spoil people's pleasure and increase doctor's bills, based on the reasoning that it cannot be possible to have too much of a good thing (Dekker, 1905, p. 24) (Figure 8.1).

The Gull's Hornbook is evidence of social tension in London society, as the habits associated with privilege were seen to violate common ideas of decency. Over the next two centuries, this tension was complicated by the transformation of nightlife in London as part of a process that the historian Craig Koslofsky has termed "nocturnalization" (2011, pp. 14-16). On the one hand, changing attitudes rendered some forms of night-time socialising respectable, even civilised and desirable, for those who could afford it. On the other hand, wealth and fashion became even more closely associated with unhealthy lifestyles.

Nocturnalisation was a process by which activities that had previously belonged by common agreement to daylight hours (such as leisure, entertainment, religion and politics) were extended into the night. This gained legitimacy owing to a change of mindset regarding how to police night-time movements that occurred around the mid-seventeenth century. Rather than shutting down neighbourhoods completely, the authorities turned their attention to proposals to make the hours of darkness safer and public interactions more civilised. The marks of this transformation could be seen in the City's nightscape. European cities were quite literally "enlightened." The first publicly funded street lighting appeared in London between 1684 and 1694, enabled by improvements in lantern design. Coffee houses, theatres, opera houses, assembly rooms, the new banqueting hall at Whitehall, and the pleasure gardens at Vauxhall and Renelagh were lit up at night. Nocturnalisation also 


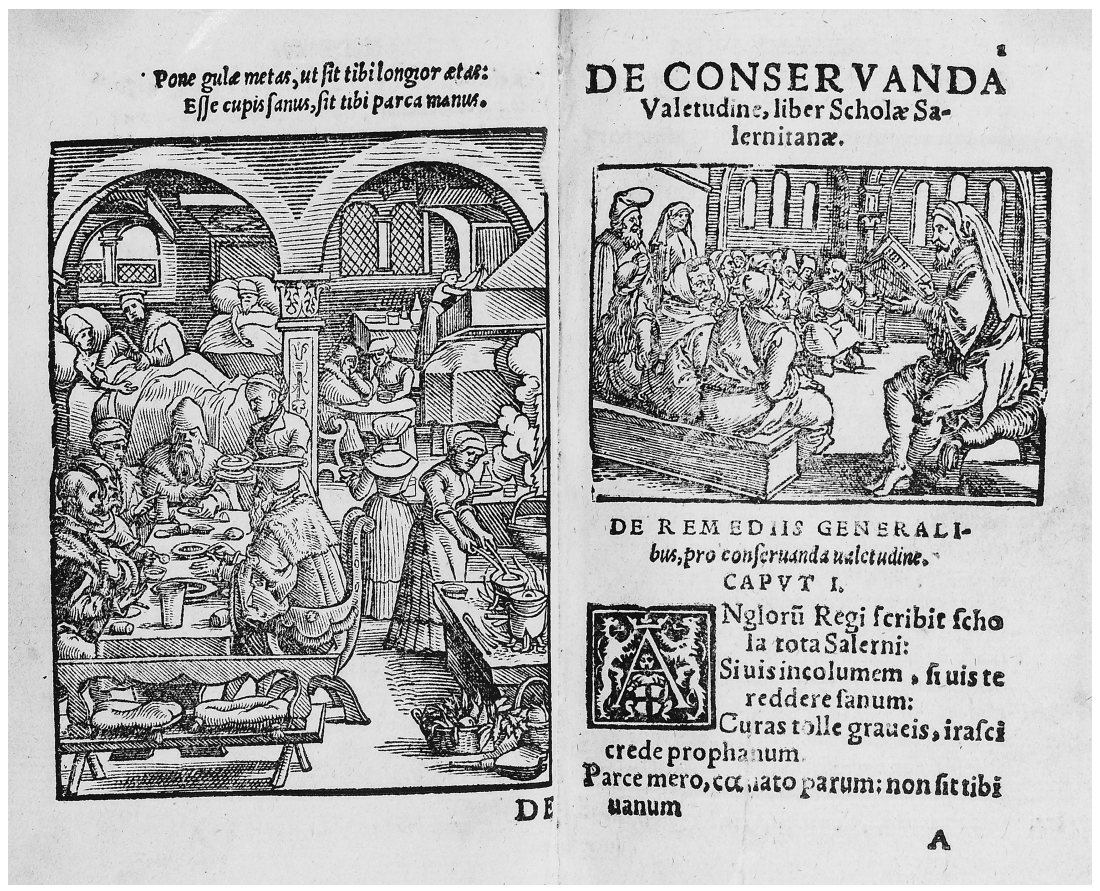

Figure 8.1 Woodcut, frontispiece and first page from the Regimen sanitatis Salernitanum (1553). Courtesy of the Wellcome Collection.

affected the functioning of wealthy households, which acquired new bedding to accommodate guests and chairs designed for daytime naps. Sitting up socialising and playing cards became fashionable in well-to-do houses in both the country and the city (Koslofsky, 2011; Handley, 2016, pp. 163-173).

The relationship of the Enlightenment to this process is complex. Public urban spaces were a vital element in the spread of Enlightenment ideas and the culture of politeness, enabling the conditions of open market and free mixing of social classes in which a society intent on consuming new ideas could flourish. In particular, coffee houses, notorious for their late opening times, provided reading material such as newspapers and periodicals, like the Tatler and the Spectator, as well as a meeting place for various clubs, making them a venue for the discussion of issues of government and civic virtue. During the eighteenth century, London was seen as a model for the progressive mix of people of varying ranks, sex and religious affiliations, which could be seen in resorts such as Vauxhall (Porter, 1981, pp. 11-13; Koslofsky, 2011, pp. 151-162; Outram, 2013, pp. 15-16). A number of Enlightenment philosophers, notably David Hume and Adam Smith, saw the moderate use of night hours for socialising as having multiple civic benefits. Gatherings of elite society strengthened 
commercial ties, advanced knowledge in the arts and sciences, improved manners and enhanced human feeling (Handley, 2016, pp. 163-164).

\section{Sleep and the pursuit of happiness}

Concurrent with this civic ideal, there was an alternative Enlightenment view of sleep - one which idealised nature and rural life, encouraging the wealthy elite to eschew the artifice associated with luxury and indolence and turn to "natural" habits of sleeping, exercise and diet. Echoing the treatise on fishing written for a gentry readership two centuries earlier, John Locke's highly influential essay Some Thoughts Concerning Education, first published in 1693, advocated fresh air and early rising as the staples of a young gentleman's upbringing:

He that, from his Childhood, has, by a setled Custom, made Rising betimes [before the expected time; early] easie and familiar to him, will not, when he is a Man, waste the best and most useful Part of his Life in Drowziness and Lying a-bed. If Children therefore are to be called up early in the Morning, it will follow of Course, that they must go to Bed betimes; whereby they will be accustomed to avoid the unhealthy and unsafe Hours of Debauchery, which are those of the Evenings: And they who keep good Hours, seldom are guilty of any great Disorders.

(Locke, 1695, §21)

The author of the treatise on fishing believed that early rising prolonged life, and Dekker had seen the gull's disordered sleeping habits as an offence against decency. For Locke, the ultimate purpose of good habits was not to please society, or even to live to an old age, but to further the pursuit of liberty and happiness. Health was a necessity to happiness, as it was understood by Locke. He summed up his definition of happiness in the opening sentence of Some Thoughts: "A Sound Mind in a sound Body, is a short, but full Description of a Happy State in this World" (Locke, 1695, \$1). Liberty denoted independence, self-reliance and the ability to manage one's own affairs. This was not a self-indulgent freedom. Luxuries and inherited wealth were a threat to liberty when they impeded the development of self-reliance and robust health. Locke therefore advised parents not to be overly protective of their children but to bring them up in a similar manner to the sons of farmers, allowing them few comforts, and freedom to roam outdoors. He even suggested giving them shoes that let in water (Locke, 1695, \$4-9; Tarcov, 1984, pp. 77-86).

Underlying this advice was a belief in the plasticity of the human constitution. Reflecting on the physiological differences found between Europeans and the inhabitants of newly discovered territories, a number of thinkers drew the conclusion that environment was the key factor. Locke reasoned that if the indigenous peoples of hot countries were able to endure the sun because they allowed their children to go naked, then English children were less likely 
to become ill if they had become acclimatised to cold and damp weather from an early age (Locke, 1695, \$5). This was partly related to an idealised Enlightenment concept of the "natural" man who exists in a more innocent state, liberated from the corrupting effects of civic life and the pursuit of luxury (Outram, 2013, pp. 58-62). Locke regarded artificial environments as having a degenerating and effeminising effect upon the constitution. He framed good health in masculine terms. A strong constitution produced the "man of business" and the soldier, whereas anything "soft" or "feminine" spoiled a child's health (Locke, 1695, \4, 9, 15, 21).

This concern with environment extended to the sleeping environment. Locke disapproved of feather mattresses. A soft mattress, he claimed, "melts and dissolves the body" (Locke, 1695, \$22). Here it is likely that he was influenced by the controversial writings of the Behmenist Thomas Tryon, who compared sleeping in an old feather bed to burying one's face in a privy. Tryon promoted vegetarianism and an ascetic lifestyle, believing that many of the "hot" luxuries enjoyed by the upper classes such as meat, alcohol, tobacco, large fires and soft beds were debilitating. Amongst the perils of feather beds, upon which he elaborated, were the retention of sweat, bodily odours and diseases passed on by former (dead) occupants, the harbouring of excrement and parasites, the overheating of the back and kidneys and a general faintness caused by drying out of the bodily fluids. He recommended instead sleeping on straw pallets covered with flock (rag stuffed) or wool quilts, which were common in less well-off households or reserved for servants and children in wealthy households (Handley, 2016, pp. 124-126). In humoral terms, the aim of Tryon's "clean" health regimen was to keep the body cool through the avoidance of "hot" food and the free access of fresh air, even at night (Tryon, 1682; Smith, 2004).

Locke applied these ideas of health, based on ancient humoral medicine, to a new agenda - that of promoting reason and natural freedom as the basis of self-government. To this end, he made an exception to the general rule of retiring at 8 o'clock, which was that older sons should be allowed occasionally to stay up until midnight to share a glass of wine with company. This exception exposed a contradiction inherent in Locke's programme of education. Whereas he advised a health regimen based in conditioning children to be comfortable in nature and the outdoors, the development of reason and enlightened thought was based upon the sociability of an artificial, urban environment that increasingly ignored the natural patterns of night and day. Locke attempted to resolve this conundrum by making a distinction between civil and uncivil night-time socialising, between "midnight revels" and a late-night “chat” (Locke, 1695, \$21).

\section{Husbanding time}

While Locke addressed his Thoughts on Education to the landed elite, he intended the principles to be universally applicable. If education rather than birth was the key to liberty, the pursuit of happiness was open to all. For those without 
inherited fortunes, however, wealth-management rather than health tended to be the dominant motivation put forward in favour of early rising. Texts on estate management emphasised the importance of making good use of time and avoiding expensive habits and company. Early bedtimes and early mornings were part of an economy that promised wealth and independence to men who followed the principles of temperance, frugality, industry and sobriety.

By the eighteenth century, this principle of economy was being taught to those who aspired to make their fortunes through trade in a genre of educational handbooks Lawrence Klein has labelled "Very Useful Manuals" (1995, pp. 362-380). Earlier in this chapter, we came across the concept of early rising as a rule of household management in Fitzherbert's book on husbandry. This theme continued in Very Useful Manuals aimed at a City, rather than a rural, audience, which laid stress on the importance of "husbanding time." "Above all Things learn to put a due Value on Time," wrote John Barnard in A Present for an Apprentice, "and husband every Moment, as if it were to be your last: In Time, is comprehended all we possess, enjoy, or wish for; and in losing that, we lose them all" (1740, p. 25). Here the verb "to husband" was used in the sense of "to manage to best advantage," but the concept was closely connected to the role of a husband as the manager of the family assets.

In this way, trading guides stressed the business sense of proverbs such as "early to bed ..." and "one hour's sleep before midnight ... ." As with considerations of health, this had its basis in custom. Traditionally, daytime in urban areas was associated with work and profit. Many medieval guilds had outlawed night-time activities. In particular, trade during the hours of darkness was associated with deception as bad lighting made it difficult to assess the value of goods being sold. In London, the ban on a number of trades continued into the early modern period because of the noise made at night. Smiths, pewterers and founders, for instance, were subject to a fine if heard working between the hours of curfew and 4 o' clock in the morning (Ekirch, 2005, pp. 155-157; Griffiths, 2008, pp. 39-40). The underlying principle was that citizens required quiet and rest at night. This did not necessarily mean that bedtime was at curfew. In reality, the necessity of completing domestic or work-related chores meant that many continued to work into the night on tasks that would not disturb neighbours (Ekirch, 2005, pp. 157-164). However, as Fitzherbert had noted, there was a cost-benefit calculation to be done when deciding whether or not to continue work after dark. The popular idiom "not worth the candle," based on the French saying "the game's not worth the candle," expressed the idea that the profit from any activity continued into the night must exceed the cost of lighting (Entry "candle," in Ayto, 2009).

Whether or not proverbial wisdom concerning early bedtimes continued to reflect the reality of night-time labour in the early modern era, moralists disapproved strongly of two habits associated with upper-class profligacy: lying in bed during sunlight hours, and night-time sociability. It was this, rather than being awake after dark in itself, that was associated with luxury and excess. As artificial light was expensive and inadequate, rising early to make the best 
use of daylight was simply common sense for the vast majority. It was in this context that Benjamin Franklin made his famous reference to the old English proverb. Less well known is a satirical letter he published in a Paris magazine in 1784 entitled "An Economical Project." This mocked the profligacy of the elites of Europe who sought increasingly sophisticated lighting technology for evening entertainments but failed to recognise the value of sunlight. The fictional writer expresses surprise at learning that the sun rises between six and eight in the morning, and that, simply by rising before noon, he could have light for free (Koslofsky, 2002, p. 743). The common-sense husbanding of time was therefore figured starkly in contrast to the prevailing fashions of the ancien régime.

This was not dissimilar to sentiments expressed in London publications. The Very Useful Manuals disapproved of any pastime that involved unnecessary expense, and this was expressed in terms of social identity. In A Present for an Apprentice, Barnard made a distinction between habits suitable for "a man of business" or "citizen," and those he disdainfully referred to as a "gallant," "courtier," "fortune-hunter" or "fop." Pursuits that were unsuitable for men of business included attending the playhouses, operas or concerts, drinking in taverns, dancing, gambling and masquerades. Nor should he attempt to learn an instrument or associate with professional musicians. The "fop's" love of showy clothes was effeminate and foreign, as well as ruinous: "in a citizen, an affectation of this kind is never to be pardoned." Instead, the tradesman should pursue recreation that involved little or no expense, such as reading, viewing fine landscapes, fresh air and good weather. It is notable that this regime rejected expensive night-time City pleasures in favour of natural pleasures that could be appreciated during daylight. Recreation, economy and sleeping habits were inextricably combined in a way of life strongly defined against the kind of dissipated style of living evoked by Dekker in the previous century (Barnard, 1740, pp. 15, 35-40). Unlike the gull, the tradesman must resist the temptation to gain social credit by aping upper-class habits of dress and socialising, if he is to succeed. Barnard foresaw social ridicule: "Looseness and prodigality will be called living like a Gentleman, and you will be upbraided with meanness, and want of spirit, if you dare to persist in the ways of economy and virtue" (Barnard, 1740, p. 27).

Although the trading personality must separate himself in dress and lifestyle from the gentleman, the aim of success in trade was social advancement. These texts held out the possibility that, by careful economy of time and assets, a person of no fortune could gain the wealth and property that was associated with the landed gentry. The Compleat Tradesman, a guide to trading written by a London merchant, told the story of a landed gentleman from Surrey who was forced to rent out his land to a farmer to pay off some debts. Before the lease was finished, the farmer asked the landlord if he would sell him the land outright. Surprised that someone from such a modest background could afford to become a landowner, the gentleman asked the farmer to explain his success. The farmer replied, "You lay in Bed, or took your pleasure, and sent others 
about your Business: And I rose betimes and saw my Business done myself." In case it is not obvious, the author expounds the moral of this story: "in all Countries the Sun riseth in the Morning, Occasion then combining her Head, and putting the Lock of successful Opportunity into your hand" (Compleat tradesman, 1684, pp. 4-5).

The contradiction in these texts was that they conceived of a social mobility made possible by separating oneself from the society of those of the social station they wished to join. Daniel Defoe suggested that, in reality, many apprentices succumbed to such social pressures and participated in City nightlife:

We scarce now see a tradesman's apprentice come to his fifth year, but he gets a long wig and a sword, and a set of companions suitable; and his wig and sword being left at proper and convenient places are put on at night after the shop is shut, or when they can make a flip out to go a raking in ... from this cause it is principally, that so many apprentices are ruin'd, and run away from their masters before they come out of their times.

(Defoe, 1726, p. 129)

\section{Noxious damps and vapours}

Both Locke's treatise on education and the tradesmen's books promised health and happiness at the expense of the immediate pleasure of evening socialising. This was a problem, because business and pleasure were closely related in eighteenth-century London. Nothing demonstrates so clearly the contradictions inherent in Enlightenment society's cultivation of sociability and the pursuit of health and happiness as the life of physician George Cheyne. Born near Aberdeen, Cheyne came to London in the first decade of the eighteenth century. Looking back on his life as a young man, he described how his way of living radically changed upon entering London society:

I found the Bottle-Companions, the younger Gentry, and Free-Livers, to be the most easy of Access, and most quickly susceptible of Friendship and Acquaintance, nothing being necessary for that Purpose, but to be able to Eat lustily, and swallow down much Liquor.

(Cheyne, 1734, pp. 325-326)

It was not only the pleasure-seeking lifestyle that made this circle of acquaintance attractive to a man in Cheyne's position. His friends amongst the gentry were not only his companions, but also his clients. His contemporary Bernard Mandeville describes a similar way of building up a professional base in London's social scene:

if you can Chat, and be a good Companion, you may drink yourself into Practice ... [or] you must ... keep a set of Coffee-Houses, observe your 
certain Hours, and take care you are often sent for where you are, and ask'd for where you are not.

(cited in Guerrini, 2000, p. 5)

In 1705 Cheyne's health collapsed. With his health and practice in ruins, he retired to the country to reflect upon the state of London society. He spent the rest of his professional career writing against the luxurious lifestyle of the upper classes in a series of highly popular health guides. His autobiography reads like a religious conversion narrative, except that it was for the sake of his health, more than his soul, that he radically changed his living habits. He adopted a diet of milk and vegetables. He was in bed by 10 o'clock every night and rose at six (Cheyne, 1734, pp. 361-362; Handley, 2016, pp. 36-37).

In a chapter on sleep and watching in An Essay of Health and Long Life, he reiterated the old argument that it was unnatural to stay awake at night and to sleep during the day, but with more force and at more length than physicians of previous centuries. The night air was full of damp, heavy and harmful vapours, he warned. As digestion was the main activity of the body during sleep, it was nonsensical to go to bed many hours after eating or with a belly full of drink and a heavy supper. Lying "lolling and soaking" in a warm bed was the worst possible thing for the constitution, "it thickens the Juices" and "enervates the Solids." He praised early rising in Romantic terms. Rise early, he promised, and enjoy:

The Influence of the fresh, benign, Morning Air, the retreating of all the noxious Damps and Vapours of the Night, together with the Clouds and Heaviness, that are thrown upon the Brain from Sleep; and lastly, that Chearfulness and Alacrity that is felt by the Approach or Presence, of that glorious Luminary the Sun, which adds a new Force to the Heart, and a Spur to the Spirits.

(Cheyne, 1725, pp. 77-88)

At this time of day, the body would have energy, a clear mind, and gentle passions.

The popularity of Cheyne's publications, which went through multiple editions, suggests that many shared his perception that the rhythms of socialising and sleeping in eighteenth-century society had become wildly off-kilter. This is further evidenced by entries in gentlemen's magazines. In 1710, a contributor to the Tatler decried the late hours that had become fashionable in London. He recollected approvingly a time when the curfew bell was the signal for putting out the candle and going to bed. The time of rising should be six, he insisted. Research conducted by Sasha Handley also suggests that the new fashion was not always welcomed even by those who practised it. Both men and women expressed in their diaries an inner conflict between the desire and need for sleep, and the requirement to fulfil the obligations of politeness (Handley, 2016, pp. 151-163). 
The belief that the new fashion for socialising was unnatural and bad for the health persisted into the second half of the century. In his guide to healthy living, An Easy Way to Prolong Life (1780[?]), John Trusler regarded sitting up late and sleeping in as unnatural, and therefore one of the worst things for the constitution. Sunset, the "shutting in of the day," was the time that nature had appointed for all living things to rest. Forcing the animal spirits to continue active at a time of day when they naturally withdrew hastened old age by drying out the body and made the face appear flushed. Sleeping late delayed evacuation of excrement from the body, causing blockages that dulled the brain and the senses. If fatigue made it necessary to sleep a little longer in the morning, this should not be past 9 o'clock (Trusler, [1780?], pp. 9-11).

\section{Enemies of sleep}

Not all were convinced by the rhetoric of health manuals and gentlemen's magazines. Rejecting the advice of physicians, proverbial wisdom and the new polite sociability, a portion of London society embraced a hedonistic definition of liberty and asserted the privileges associated with the old order.

The problem with the Lockean universal moral gentleman wasn't simply one of lost pleasure. By adopting rules of temperance, prudence and self-denial that could be shared by tradesmen, one ran the risk of looking like a tradesman. In an unfinished play begun by John Vanbrugh in the 1720s, an aristocratic lady replies to her husband's criticism of her habit of staying out until 3 o'clock in the morning: "your eleven has a dull, drowsy, stupid, good-for-nothing sound with it. It savours much of a mechanic, who must get to bed betimes that he may rise early to open his shop." Her husband cannot object to her late-night socialising, she reasons, because her companions are of the highest social status (cited in Koslofsky, 2011, p. 146). Two conflicting ideas of polite conduct arose: according to the first, laws regarding times of rest and rising should be governed by rules of health, convention and the needs of domestic management; according to the second, the respectability of social activities depended not on the time of day but on the company that was kept.

Class tensions were most pronounced, however, when it came to those who rejected notions of civility altogether and refused to live by any rule. The "rake" was another successor to the Jacobean gull. "Rakes" were upper-class young men and their associates amongst the intelligentsia and artistic circles, who were given to gambling, drunkenness, sexual licence, gratuitous violence and destruction of property. Whereas the gull had been boorish out of foolishness, the rake committed acts of incivility deliberately for the pleasure of shocking society. Much of the rake's escapades took place at night-time in taverns, brothels and alehouses, instigated by notorious libertine clubs, the names of which inspired fear amongst respectable citizens - the Bugles, the Scowrers, the Hectors and the Mohocks, to name but a few. Roger Ekirch in his study of early-modern night-time culture includes an entire chapter on the unruly behaviour of aristocratic youths after dark. Spilling out into the streets, the 
lawlessness of rakes resulted in assaults on the watch, on private property and on innocent citizens attempting to reach home at night, or whose homes were broken into (Bryson, 1998, ch. 7; Ekirch, 2005, ch. 8). As John Gay put it in his poetical portrait of London streets by night:

Now is the time that rakes their revels keep;

Kindlers of riot, enemies of sleep ...

(Gay, 1716, p. 52)

Some very prominent people embraced the libertine lifestyle. Charles James Fox, the leader of the Whig Party in the late eighteenth century and a close friend of Prince George, was known to sit up all night gambling before appearing next morning to speak at the House of Commons (Linanne, 2006, pp. 233-234). The behaviour of rakes at night was a deliberate flouting of the expectations of sleeping patterns established in medicine, law and notions of civility, and an example of a form of social posturing Anna Bryson has termed "anti-civility" (1998, pp. 252-253). At one level, anti-civility was a way of identifying oneself with the highest ranks of society. Whereas those who had made their own fortunes sought to establish themselves as gentlemen through observing the rules of politeness, those who were gentlemen by birth had no need to be careful of their reputations. In fact, acts of incivility or lawlessness could be a way for the landed classes to assert the centuries-old privileges of birth in an urban context where the meaning of "gentleman" was becoming blurred. The most notorious example of this kind of class-conscious anticivility took place on Bow Street in 1663. Sir Charles Sedley, Lord Buckhurst and Sir Thomas Ogle came out onto a balcony next to the cook's house where they were drinking and, in full view of the watching crowd, pulled down their breeches and defecated in the street. Sedley then stood naked on the balcony preaching blasphemy. These actions have been interpreted by Anna Bryson as gestures of contempt and superiority by these men against their audience of tradesmen (1998, pp. 254-255, 262-263).

Similarly, night-time "frolics" were a way for the upper classes to express disdain for the rules of proper conduct that generally applied to London citizens. Medieval and early modern legislation in some European cities had exempted the nobility from rules around carrying lights, swords and firearms after dark, and a sense of entitlement lingered. In 1641, Lord Fielding was highly offended when his carriage was stopped by the watchmen when travelling through London at 1 o' clock in the morning. The constable in charge was forced to retract, explaining that he did not recognise the nobleman's carriage in the dark (Griffiths, 2008, p. 335; Ekirch, 2005, pp. 66-67). Double standards were sometimes upheld by the courts. A case brought in 1687 in which a watchman was killed by the young sons of noblemen in a drunken clash in the early hours of the morning was found to be an "accident" (Koslofsky, 2011, pp. 149-150).

The aristocracy saw disorder as solely the privilege of their own class. In a late seventeenth-century play called The Scowrers, a lower-class imitator "scours" a 
tavern full of tradesmen and is reprimanded by the leader of the nobles' gang for attempting to "usurp the sins of gentlemen" (cited in Bryson, 1998, p. 250). Acts of anti-civility led by aristocratic youths were deeply conservative. They asserted an aristocratic form of masculinity, based in codes of honour and displays of violence, as opposed to the new codes of polite masculinity. They laid claim to a right to libertine behaviour that was a privilege only of the landed classes, vying against the new class of prudent, bourgeois gentlemen. Public acts of disorder and incivility at night were also a reaction against eighteenthcentury attempts by the authorities to civilise night-time sociability, sometimes resulting in the smashing of street lamps and insults or attacks on watchmen. They fought to defend an older version of noble male dominance of the night against both the feminised, civilised nightlife represented by brightly lit theatre, coffee houses and pleasure gardens, and the wisdom of educational handbooks linking early bed times with health and respectability (Kelly, 2006, pp. 776-782, 792-795; Koslofsky, 2011, pp. 142-149).

At one level this was pure snobbery. A fashionably dissolute lifestyle was a way for those born into wealth to distinguish themselves from the middle classes. However, in the poem "Night, an Epistle to Robert Lloyd" (1761), Charles Churchill offers a more subtle critique of contemporary attitudes. Churchill was a clergyman (before his notoriety forced him to give up the profession) and a member of the scandalous gentleman's club The Franciscan, which engaged in drinking, sexual liaisons and mock religious rites (Sambrook, 2004). In this poem, he pictures himself in the company of his friend and drinking companion Robert Lloyd at a late hour and imagines the disapproval of civil or "prudent" society:

The wretch bred up in method's drowsy school

....

Turns up his eyes to think that there should be,

Among God's creatures, two such things as we;

Then for his nightcap calls, and thanks the powers

Which kindly gave him grace to keep good hours.

(Churchill, 1933, 11. 19-30)

Churchill's night is the time for true society, when troubles are eased by companionship - the companionship of a "narrow circle of our chosen friends" and the companionship of women, which "makes society complete." Night is a time of mirth, good humour and wine (Churchill, 1933, 11. 289-294). He extols the equity of night-time society, when the dress that distinguished social rank is cloaked in darkness and people are revealed for who they really are. Roger Ekirch has argued that a large part of the appeal of nightlife was that it "revolutionised the social landscape." In brothels and taverns, the highborn mixed with the lowest in society, sometimes in disguise so that their rank could not be recognised. The politeness, deference and reserve that dominated social relations during daylight hours was cast aside, replaced by physical intimacy 
and candid conversation (Ekirch, 2005, pp. 210-226). This is Churchill's chosen society, which he compares favourably to the society of daytime, ruled by the demands of commerce, rank and self-interest (Figure 8.2).

The poem is an attack on the coalition of medicine, advice manuals and proverbial wisdom that combined to censure night-time socialising. In Churchill's poem, the whole concept of "good" and "bad" hours are merely a social construct on which nobody can agree on the details, and many pay only lip service. The prudent man who goes to bed at 10 o'clock and the socialite who lives his life "in downright opposition to the sun," both claim for themselves the identity of the respectable man who "keeps good hours" (Churchill, 1933, 11. 31-40). Though quite a long time before the poem was written, we might think of the 1687 trial in which a number of character witnesses testified that the young noblemen who killed the watchman in the early hours of the morning "kept good hours," with apparently no sense of irony (Koslofsky, 2011, pp. 149-150). Churchill also suggests that many were in the practice of meeting prostitutes or engaging in drunken behaviour outside the confines of the City gates, so as to protect their reputations (1933, 11. 320-324). He is irreverent towards the prevailing Hippocratic medicine of the time objecting that one

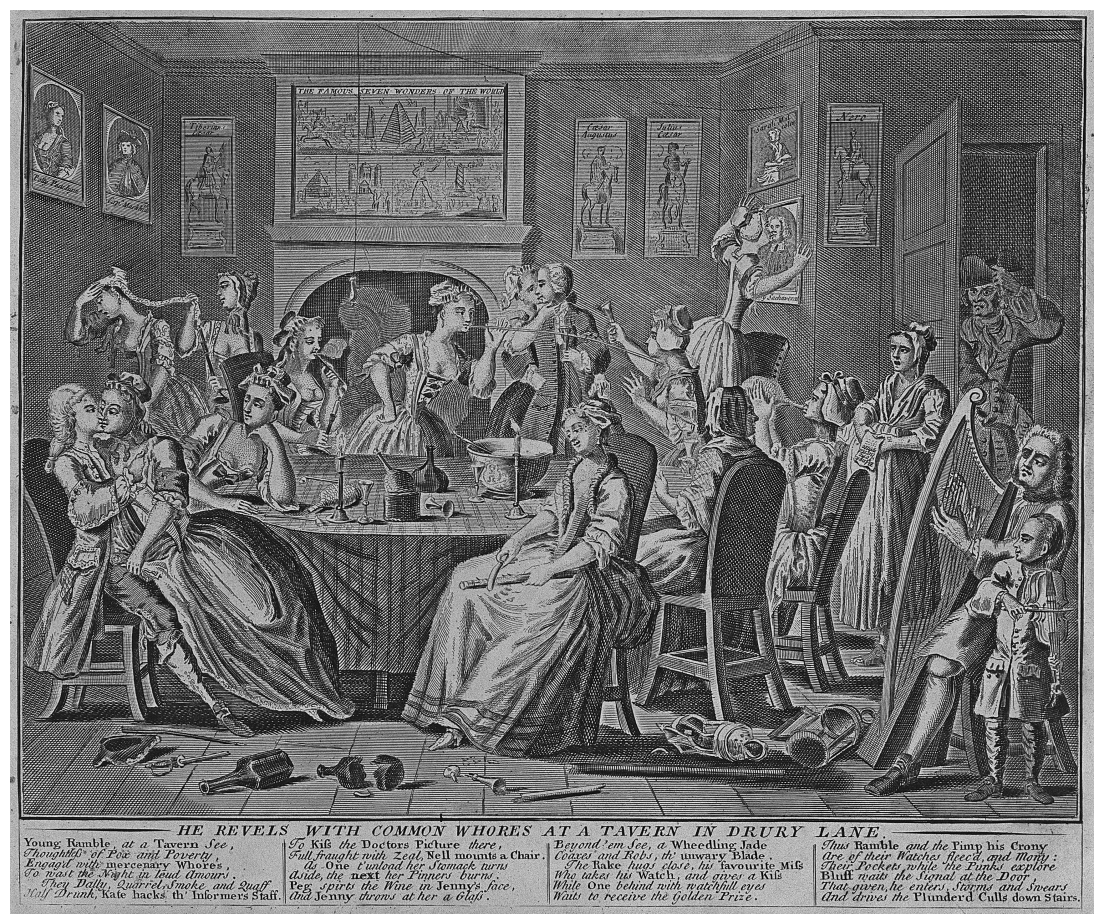

Figure 8.2 The rake carouses in a tavern full of prostitutes. Engraving by Thomas Bowles, 1735. Courtesy of the Wellcome Collection. 
rule concerning sleep could not be applied to people of varying constitutions (Churchill, 1933, 11. 57-84). Such rules also offended against individual liberty because they denied the right of a man to decide for himself how best to use time in light of his own circumstances (Churchill, 1933, 11. 49-56).

Churchill saves his most caustic attacks for traders: "slaves to business, bodies without soul/ Important blanks in Nature's mighty roll" who "solemnize nonsense in the day's broad glare" (1933, 11. 7-9). He is scathing of those who have made their fortune through trade and who live to a rigid schedule. He sees the values of the trading class as undermining true relationships: "upstart knaves grown rich, and fools grown great" who "meanly overlooks a friend distressed" (Churchill, 1933, 11. 88-90). Such people lack individuality and soul, who live their lives "clockwork-like" (Churchill, 1933, 1. 25).

Churchill had his own axe to grind and his portrayal of night-time society is romanticised. Night-time gatherings often ended with prostitutes stealing from their clients while they were drunk or asleep. The revelry of gentleman's clubs could erupt into violence against pedestrians, women and watchmen that ended in injury, rape and death (Ekirch, 2005, pp. 222-226). His alternative vision of liberty is unsettling, nevertheless, because it suggest an underlying paradox at the heart of the "early to be, early to rise" motto. Whereas social rules surrounding sleep purported to be civil, they could actually be deeply antisocial when they saw time in purely monetary terms and reduced human relations to a financial transaction.

\section{"Foppish" sleep}

The advocates of discipline countered the appeal of urban hedonistic living by linking early rising with robust masculinity and vitality. In both Locke's writing and the trading books, styles of living were linked to particular masculine identities - the "beau" versus the "man of business"; "disorders" and "debauchery" opposed to the man of civilised conversation and disciplined conduct. Two stereotypes of gentlemanly idleness and excess are recurrent in eighteenth-century literature: the "rake," whose behaviour was riotous (as seen in the previous section), and the "fop," who was vain, effeminate and addicted to luxury and comfort. While Locke sought to reform the conduct of the landed classes on the basis of the promise of health, liberty and independence, for an eighteenth-century middling family who relied on the precarious income from trade, the image of the idle gentleman was a spectre that endangered their very existence in polite society (Smail, 2008).

Over the course of the eighteenth century, the concern that dissolute living habits were ruinous to health developed into a concern that they were threatening the very foundation of masculine identity. This anxiety took form in the stereotype of the "fop." Appearing in the last decade of the seventeenth century, the fop was a successor to the Jacobean gull or gallant, sharing his desire to be thought refined in upper-class urban society alongside his inability to please. He was obsessed with appearance, spending large amounts of 
money on clothes and much of his time at fashionable resorts. Whereas the gull described in Dekker's guide had only St. Paul's Walk (the central isle of St. Paul's Cathedral) to show off in, by the late seventeenth century, the fop had a greater range of public spaces for polite display. The coffee house, the theatre (where he could appear in a side-box) and the public park had become haunts of the urban socialite. The antisocial nature of the fop's conduct stemmed from his narcissism, which was based in an excessive self-consciousness about the rules of politeness and a trivial approach to civility. Failing to understand that the purpose of civility was to ease social interaction, his showiness betrayed a lack of awareness of the needs of others or of what he owed to wider society (Carter, 1997).

The image of the "fop" caricatured the lifestyle of the idle rich as effeminate as well as irresponsible. "He that sets up for a Sir Fopling Flutter, instead of a compleat tradesman," wrote Defoe, "is not to be thought capable of relishing this discourse" (1726, p. 142). Concern for appearance, nice manners and a love of conversation were seen to be crossing over from the female to the male realm. As Craig Koslofsky has noted, this excess of politeness could be attributed in part to new forms of night-time sociability, which critics saw as feminising European culture. They compared the active pursuits of the countryside gentleman, such as hunting and horse racing, to the sedentary pursuits of evening leisure in the city. Men sat talking in coffee houses "like women at a Gossiping" (Koslofsky, 2011, pp. 162-163).

This effeminacy was also demonstrated in morning routine. One of the distinguishing features of the fop caricature was his tendency to waste the morning in dressing and looking at himself in the mirror. His effeminate delicacy was seen in his resistance to early rising on account of hypochondriacal fears about his health. Lord Foppington in John Vanbrugh's comedy of manners The Relapse (1696) never rose before 10 o' clock because " "tis the worst thing in the World for the Complexion," was never dressed before $1 \mathrm{pm}$ and spent his time at the chocolate house and the theatre instead of attending to business at the House of Lords (Vanbrugh, 1697, Act 2, Sc. 1).

During the second half of the eighteenth century, opposition to excessive luxury in men's lifestyle and dress became increasingly medicalised as fears increased over its enervating and emasculating effects. Medical authorities condemned rouge, powder and constrictive clothing as inhibiting the circulation of the blood and blocking the pores. On the basis of this, Enlightenment thinkers such as Rousseau and Lavater promoted a more "natural" style of dress that enabled an upright, unaffected masculine physiognomy (McNeil, 2007, pp. 396-397). Following Tryon, Locke and Cheyne, lying in a warm bed during the morning hours was also criticised. The Methodist leader John Wesley, who rose at 4 o'clock to attend prayer meetings, emphasised the importance of early rising for physical and emotional, as well as spiritual, health (Handley, 2016, pp. 79-81).

The chivalric ideal of education for boys became popular as a way of countering the debilitating luxury and over-politeness that was believed 
to be weakening the population. This was partly inspired by the Scottish Enlightenment. Enquiring into the origins of civilisation, Enlightenment thinkers suggested that the age of chivalry was an important transitional stage from barbarism to a refined society. As Locke had suggested earlier, the new system of education placed an emphasis on teaching young men to endure hardship, in order to secure manliness and independence. Effeminate delicacy and excess were regarded as the enemies of liberty (Cohen, 2005).

Writing in the first half of the nineteenth century, William Cobbett (17631835) associated early rising and the rejection of comfort and luxuries with robust masculine health, industry and success. Cobbett rose from relative obscurity as a younger son of a farmer and publican to become a member of parliament. He attributed his success to his habit during his early years in the army of getting up at sunlight during the summer months and at 4 o'clock in winter. In his Advice to Young Men, published in 1829, he emphasised the importance of making use of "as much of the day-light and as little of the candle-light as is consistent with the due discharge of your duties." His writing exhibited a similar nostalgia for the rural lifestyle in which sleep followed the rhythms of day and night that can be found in Locke and Cheyne's work. He describes how the military men under his command were able to spend the morning fishing, walking the woods or gathering berries, on account of this habit of rising early. These habits were good for the health and passions of the body (Cobbett, 1829, \$38-39).

Cobbett not only stipulated early rising but also described how a young man should behave upon getting out of bed. It was useless to rise early if the morning was wasted in luxurious habits. He should be taught to shave in cold water without a mirror, for "a looking-glass is a piece of furniture a great deal worse than useless." The vanity of staring at one's own reflection could waste up to 50 minutes in the morning and waiting for a servant to light a fire to heat the water would cause further delays in beginning the business of the day. Cobbett disapproved of the use of garments such as morning-gowns, which, he argued, was equivalent to remaining "still in a sort of bedding." "Those who first invented morning-gowns and slippers could have very little else to do," he scoffed, "These things are very suitable to those who have had fortunes gained for them by others" (Cobbett, 1829, \$38).

Cobbet's writing shares some of the concerns found in Dekker's satirical "rules for the morning" written two centuries earlier. While the culture and night scape of London had changed radically, conduct writers still looked with disapproval on late rising. By the nineteenth century, health, sleep and productive habits had become intertwined with a rejection of other luxuries such as dress, looking glasses and heated water. For Corbett, those who inherited wealth were encumbered by these luxuries. The man who could endure and make his own fortune was truly liberated. Influenced by ideas such as those of Cobbett, the indolent upper-class gentleman became a stock character in Victorian novels, always compared unfavourably with the more industrious country-folk or the energetic early riser. Mr. Lockwood in Emily Bronte's 
Wuthering Heights sleeps until 10 o'clock in the morning (Brontë, 1847, p. 135). The foppish Joseph Sedley sleeps through the sound of the din of the bugles, drums and bagpipes announcing the departure of the army for the battle of Waterloo (Thackeray, 1848, p. 265).

\section{Conclusion}

The impact of urban environments has become a matter of particular interest in twenty-first century studies of sleep and health. Has a 24/7 society created a chronically sleep-deprived population? Has the introduction of artificial light disrupted ancient circadian rhythms? (Ekirch, 2015; Williams, 2005, pp. 101-107). We can see the origins of these anxieties about modernisation in Enlightenment ambivalence concerning the impact of urbanisation. On the one hand, artificially lit urban environments were seen as progressive because they provided the space and time necessary for the social commerce on which trade and intellectual enquiry depended. On the other hand, there were fears that urban life was becoming dislocated from the natural rhythms of day and night that continued in the countryside. This was not only a matter of "good" health but also of "masculine" health. Luxurious sleep on feather mattresses that lasted through the morning was believed to soften the body, creating a delicate "feminine" constitution. While some libertines mocked the medical theories that underlay such beliefs, by the nineteenth century the kind of austere regimen recommended by Locke had come to signify robust masculinity and independence.

\section{Note}

1 This work was supported by the Wellcome Trust [grant number 109069/Z/15/Z].

\section{References}

Anon. (1496). 'The Treatise of Fysshynge Wyth an Angle.' In: J. Berners (ed.) This Present Boke Shewyth the Manere of Hawkynge [and] Hunting. 2nd ed. London: Wynkyn the Worde.

Ayto, J. (ed.) (2009). Oxford Dictionary of English Idioms. 3rd ed. Oxford: Oxford University Press.

Bahia. (1656). The Skilful Physician. London: Thomas Maxey.

Barnard, J. (1740). A Present for an Apprentice. London: T. Cooper.

Brontë, E. (1847). Wuthering Heights. London: Thomas Cautley Newby.

Bryson, A. (1998). From Courtesy to Civility: Changing Codes of Conduct in Early Modern England. Oxford: Clarendon Press.

Carter, P. (1997). 'Men About Town: Representations of Foppery and Masculinity in Early Eighteenth-Century Urban Society.' In: H. Barker and E. Chalus (eds.) Gender in Eighteenth-Century England. London: Longman, pp. 31-57.

Cheyne, G. (1725). An Essay of Health and Long Life. London: George Strahan. 
Cheyne, G. (1734). The English Malady: Or, a Treatise of Nervous Diseases of All Kinds. London.

Churchill, C. (1933). 'Night, an Epistle to Robert Lloyd.' In: J. Laver (ed.) Poems of Charles Churchill. London: The King's Printer, pp. 62-72.

Clarke, J. (1639). Paroemiologia Anglo-Latina. London.

Cobbett, W. (1829). Advice to Young Men, and (Incidentally) to Young Women. London.

Cohen, M. (2005). “"Manners” Make the Man: Politeness, Chivalry, and the Construction of Masculinity, 1750-1830.' Journal of British Studies 44(2), pp. 312-329.

Defoe, D. (1726). The Complete English Tradesman. London.

Dekker, T. (1905). The Gull's Horn-Book. Ed. R. B. McKerrow. London: De La More Press.

De Mediolano, J. (1528) Regimen sanitatis Salerni. Trans. T. Paynell. London.

Ekirch, R. (2005). At Day's Close: A History of Nightime. London: Phoenix.

Ekirch, R. (2015). 'The Modernization of Western Sleep: Or, Does Insomnia Have a History?' Past and Present 226(1), pp. 149-192.

Fitzherbert, J. (1530). Here Begynneth a Newe Tracte or Treatyse Moost Profitable for All Husbande Men. London.

Franklin, B. (1786). The Way to Wealth. Hudson, NY.

Gay, J. (1716). Trivia: Or, the Art of Walking the Streets of London. London: Bernard Lintot.

Gratarolo, G. (1574). A Direction for the Health of Magistrates. London.

Griffiths, P. (2008). Lost Londons: Change, Crime, and Control in the Capital City, 1550-1660. Cambridge: Cambridge University Press.

Guerrini, A. (2000). Obesity and Depression in the Enlightenment: The Life and Times of George Cheyne. Norman, OK: University of Oklahoma Press.

Guevar, A. (1548). A Dispraise of the Life of a Courtier. London.

Handley, S. (2016). Sleep in Early Modern England. New Haven, CT: Yale University Press.

Harvey, K. (2005). 'The History of Masculinity, Circa 1650-1800.' Journal of British Studies 44(2), pp. 296-311.

Herbert, G. (1640). Outlandish Proverbs. London.

H. N. (1684). The Compleat Tradesman, or, the Exact Dealers Daily Companion. London.

Houston, A. (2008). Benjamin Franklin and the Politics of Improvement. New Haven, CT: Yale University Press.

Kelly, J. M. (2006). 'Riot, Revelries, and Rumour: Libertinism and Masculine Association in Enlightenment London.' Journal of British Studies 54(4), pp. 759-795.

Klein, L. E. (1995). 'Politeness for the Plebes: Consumption and Social Identity in Early Eighteenth-Century England.' In: A. Bermingham and J. Brewer (eds.) The Consumption of Culture 1600-1800: Image, Object, Text. London: Routledge, pp. 362-380.

Koslofsky, C. (2002). 'Court Culture and Street Lighting in Seventeenth-Century Europe.' Journal of Urban History 28(6), pp. 743-776.

Koslofsky, C. (2011). Evening's Empire: A History of the Night in Early Modern Europe. Cambridge: Cambridge University Press.

Langton, Christopher (1547). A Very Brefe Treatise, Orderly Declaring the pri[n]Cipal Partes of Phisick. London.

Locke, J. (1695). 'Some Thoughts Concerning Education.' In: Mark C. Rooks (ed.) Philosophical Works and Selected Correspondence of John Locke. Charlottesville: InteLex Corporation.

Linanne, F. (2006). The Lives of the English Rakes. London: Portrait.

Mander, N. (1997). 'Painted Cloths: History, Craftsmen and Techniques.' Textile History 28(2), pp. 119-148. 
McNeil, P. (2007). 'The Appearance of Enlightenment: Refashioning the Elites.' In: M. Fitzpatrick, P. Jones, C. Knellwolf and I. McCalman (eds.) The Enlightenment World. London: Routledge, pp. 381-400.

Miner, M. and Rawson, H. (eds.) (2006). The Oxford Dictionary of American Quotations. 2nd ed. Oxford: Oxford University Press.

Outram, D. (2013). The Enlightenment. 3rd ed. Cambridge: Cambridge University Press.

Paré, Ambroise. (1665). The Workes of That Famous Chirurgion Ambrose Parey. Trans. Thomas Johnson. London.

Porter, R. (1981). 'The Enlightenment in England.' In: R. Porter and M. Teich (eds.) The Enlightenment in National Context. Cambridge: Cambridge University Press, pp. 1-18.

Ray, J. (1678). A Collection of English Proverbs. Cambridge.

Sambrook, J. (2004). 'Charles Churchill (1732-1764).' In: Oxford Dictionary of National Biography [online]. Available at: http://ezproxy-prd.bodleian.ox.ac.uk:2167/view/10. 1093/ref:odnb/9780198614128.001.0001/odnb-9780198614128-e-5397 [accessed 9 Nov. 2018].

Smail, J. (2008). 'Coming of Age in Trade: Masculinity and Commerce in EighteenthCentury England.' In: M. C. Jacob and C. Secretan (eds.) The Self-Perception of Early Modern Capitalists. Houndmills: Palgrave Macmillan, pp. 229-252.

Smith, V. (2004). 'Tryon, thomas (1634-1703), Vegetarian and Author.' In: Oxford Dictionary of National Biography [online]. Available at: https://ezproxy-prd.bodleian.ox.ac. uk:4563/10.1093/ref:odnb/27783 [accessed 23 Oct. 2018].

Tarcov, N. (1984). Locke's Education for Liberty. London: University of Chicago Press.

Thackeray, W. M. (1848). Vanity Fair. A Novel Without a Hero. London: Bradbury and Evans. Tosh, J. (2014). 'The Old Adam and the New Man: Emerging Themes in the History of English Masculinities, 1750-1850.' In: T. Hitchcock and M. Cohen (eds.) English Masculinities, 1660-1800. 2nd ed. Abingdon: Routledge.

Trusler, J. (1780?]. An Easy Way to Prolong Life, by a Little Attention to Our Manner of Living. London.

Tryon, T. (1682). A Treatise of Cleanness in Meats and Drinks. London.

Vanbrugh, J. (1697). The Relapse; or Virtue in Danger. London.

Vaughan, W. (1600). Naturall and Artificial Directions for Health. London.

Williams, S. (2005). Sleep and Society: Sociological Ventures into the Un(Known). London: Routledge. 